\title{
Work Related Rights of Foreign Migrant Workers in Viet Nam
}

\author{
Khanh Ly, Trinh (Corresponding author) \\ Department of Criminology, Criminal Law and Social Law \\ University of Ghent \\ Universiteitstraat 4 Ghent 9000, Belgium \\ E-mail: lykhanh.trinh@ugent.be
}

Received: May 27, 2016 Accepted: July 20, 2016 Published: August 16, 2016

doi:10.5296/jad.v2i2.9523ＵRL: http://dx.doi.org/10.5296/jad.v2i2.9523

\begin{abstract}
Viet Nam today is deeper integrating into the global economy. In 2012/2013 the new Labour Code and amended Trade Union Law were promulgated and enacted. Numerous implementation Decrees and Circulars were introduced and enacted accordingly, which directly relate to the lives and work of the workers including foreign migrant workers. This article aims at examining and discussing the issues on foreign migrant workers in the contemporary Viet Nam. It is shown that despite positive changes in the new policies and laws the Vietnamese authority bodies have remain ineffectively responded to the issue of foreign labour in the context of significant economic growth.
\end{abstract}

Keywords: Foreign migrant workers, New Labour Code and amended Trade Union Law, Work related rights, TPP, AEC, Viet Nam 


\section{Introduction}

International migration has become a major concern in a globalized world. With the economic globalization, there is an increase of approximately 244 million international migrants (UN, 2015). The number of migrant workers is estimated at approximately 105 million (ILO, 2010). Asia is the top destination for international migration over the past decade with over 75 million migrants (Ibid.,). International migrants in Southeast Asian countries also increased to approximately 9.9 million from 6.5 million in 2005 in 2015 (Ibid.,). Approximately 90 per cent of the region's total migrants and 97 per cent of intra-ASEAN migrants are residing in Malaysia, Singapore and Thailand (ADB \&ILO 2014).

From the experience of the regional integration on labor mobility, within the European Union (EU) free movement of workers is one of the fundamental freedoms enjoyed by the EU citizens. Accordingly, Article 48.1 of the Treaty of Rome dated 25 March 1957 grants the nationals of Member States to freely move to work without work permits in other Member countries either for a short term or long term period. This legal provision grants the entitlement to both skilled migrant workers and unskilled EU migrant workers. They are entitled to equal treatment with the citizens of the host countries as regards employment, remuneration, dismissal, social and tax advantages and other conditions of employment and work. In addition, social rights and benefits are granted to EU migrant workers based on an equal footing with the citizens of the host countries, for instance, the right to housing, including ownership of the housing; access to training in vocational schools and retraining centres (Note 1).

Within ASEAN region, the ASEAN economic community (AEC) as a single regional common market of Southeast Asian countries created on December 2015 came into effect on January 1, 2016. One of the core fundamental freedoms recognized in the Paragraph 33 of the Declaration on the ASEAN Economic Community Blueprint is the free movement of skilled workers from ASEAN countries who are engaged in cross-border trade and investment related activities.

The free flow of skilled labour is covered under 08 occupational categories specified in 08 Mutual Recognition Arrangements (MRAs), comprising: Engineering Services; Nursing Services; Architectural Services; a framework for Surveying Qualifications; Medical Practitioners; Dental Practitioners; a Framework for Accountancy; Tourism Professionals. The labour mobility is considered as a significant labour reform of ASEAN in order to achieve better economic integration in the region. Although low and medium-skilled workers account for the majority in the intra-ASEAN labour migration (Ibid.,), the labour mobility of low skilled migrant workers are excluded in AEC.

Recognizing the significance of international migration and the necessity to protect and promote the human rights of the migrant workers, the ASEAN Declaration on the Protection and Promotion of the Rights of Migrant Workers was passed in 2007. The Regulation calls the promotion of the full potential and dignity of migrant workers in accordance with the laws, regulations, and policies of respective ASEAN Member Countries. The obligations of the host countries including the respect the fundamental rights and dignity of migrant workers 
and their family members in the host countries; protect the fundamental human rights, promote the welfare and uphold human dignity of migrant workers; promote fair and appropriate employment protection, payment of wages, and adequate access to decent working and living conditions for migrant workers; provide migrant workers, who may be victims of discrimination, abuse, exploitation, violence, with adequate access to the legal and judicial system (Note 2). ASEAN instrument on the protection and promotion of migrant workers' rights is being drafted by the Committee on the Implementation of the Declaration. As the result, unlike the EU there is no legal binding framework to promote and protect ASEAN migrant workers at regional level.

However, human rights of ASEAN migrant workers are protected under international standards. For example, the Universal Declaration of Human Rights recognizes the right of everyone to work, to free choice of employment, to just and favourable conditions of work; to form and to join trade unions for the protection of his interests (Article 23 Clauses $1 \& 4$ ). The Member States must avoid different standards of treatment with regard to citizens and non-citizens that might lead to the unequal enjoyment of economic, social and cultural rights (Note 3).

In recent years, Viet Nam is deemed to a destination of opportunities for foreign labour, particularly the skilled workers. According to the Expat Explorer survey conducted by the HSBC Group, the country is one of the most attractive destinations for expats. The surveyed expats view Viet Nam as a low cost-effective destination. 62 per cent of expats regard the improvement in the quality of life, and 75 per cent look on the higher salaries in Viet Nam (HSBC, 2014).

Despite the increased number of foreign migrant workers in Viet Nam, this is an almost neglected subject of studies. This is partly due to a fact that Viet Nam has long been viewed as a sending country of migrant workers. The economic growth has led to a change that Viet Nam nowadays is both a receiving country and a sending country of migrant workers. However, in practice, more attention is paid to the issue of Vietnamese working overseas. For example, the ILO is running a project on tripartite action for the protection and promotion of the rights of migrant workers in the ASEAN Region for a number of years. But the project only target at Vietnamese working overseas. In 2013 the Department of Overseas Labour was established by the Minister of the Ministry of Labour, Invalids and Social Affairs (MOLISA). It is responsible for state management over Vietnamese working overseas. There is no specialized authority body responsible for managing and support the foreign migrant workers in Viet Nam.

This paper examines the work related rights of foreign migrant workers in Viet Nam, a member country of ASEAN. The country is a case study to argue that there is an interconnection between the respect of foreign migrant workers' rights and their contribution to the growth of the Vietnamese economy. In the following section I will examine and analyze the problem of the Vietnamese labour market concerning skilled labour shortage, low labour productivity and its needs for skilled foreign migrant workers. Then I argue that despite the positive change in the new Vietnamese labour migration policies and laws it is 
still ineffective to meet the country's need for high-skilled immigration on the one hand and to protect the human rights of the foreign migrant workers on the other hand.

In order to support this argument, the paper will analyse the disadvantages that the foreign migrant workers in Viet Nam are facing under the new legal framework in particular to their work related rights. The foreign migrant workers are neither entitled to social and economic benefits equally to the Vietnamese citizens nor granted the right to political participation, including the right to vote or join the state authority bodies at all levels. In addition, the new labour migration policies and laws reveal the labour inflexibility to attract skilled permanent residents.

The article closes with a discussion and conclusion on how to improve the legal framework in order to protect and promote the work related rights of foreign migrant workers in Viet Nam. It contributes to fulfill the obligations of the Vietnamese State to the international standards for the promotion and protection of the human rights of the foreign migrant workers, attracting more skilled foreign labour in the country for the development of its labour market and economy. In addition, particularly in the contemporary context, data used in this article are collected from published articles and reports, relevant policies and legal acts. And more, the manuscript uses the national survey-labour productivity in Viet Nam: practices and solutions by the General Statistics Office-GSO in 2016.

\section{Economic Growth and a Snapshot of Foreign Migrant Workers in Viet Nam}

\subsection{Economic Growth in Viet Nam}

In 2015 foreign direct investment (FDI) in Viet Nam reached a record of US\$24.1 billion, increased by 10 per cent compared with 2014 (Ministry of Planning and Investment, 2016). The Republic of Korea is Viet Nam's largest investor with the total capital of US\$ 6.98 billion, accounting for 28.9 per cent, followed by Malaysia with the total investment capital of US\$ 2.47 billion, accounting for 10.2 per cent; Japan with the total investment capital of US\$ 1.8 billion, accounting for 7.4 per cent, and Taiwan with the total investment capital of US\$ 1.46 billion, accounting for 6 per cent of the total FDI in the country. The three major FDI sectors include manufacturing and processing, accounting for 68 per cent; followed by electricity, gas, water, steam and air conditioning system production and distribution, accounting for 11.6 per cent and real estate sector, accounting for 9.9 per cent of the total registered FDI. Ho Chi Minh City is the leading province attracting the highest amount of FDI followed by Bac Ninh and Binh Duong province (Ibid.,).

Foreign investors are seeing Viet Nam as their new investment destination. For example, Samsung has left China to invest $\$ 3.38$ billion (Ngan Anh, 2014) to build its second mobile phone factory in Thai Nguyen Province, Viet Nam. In addition, it has recently announced to stop TV production in Thailand after the announce of a US\$ 560 million investments to build a consumer appliances complex in Viet Nam (Hyunjoo, 2015). Similarly, Intel is moving a part of its manufacturing in Malaysia to Viet Nam to maintain profits (Tuoi tre News, 2015a). The major reasons for these move of Other Multi-national Corporations to Viet Nam is the cheap labour cost, strategic location and the investment attractive policies of the Vietnamese 
authority bodies, and also the incident that Viet Nam has just successfully concluded the Trans-Pacific Partnership (TPP).

Export of Viet Nam continuously increases. In 2014 it became the biggest exporter to the United States compared with other South-East Asian countries (Tuoi tre News, 2015b) with the total value of US\$21.85 billion in 8 months of 2015. Other two biggest export partners are the EU with the total exported product value of US\$30.75 billion and ASEAN countries with the total exported product value of US\$12,31 billion (Viet Nam Customs, 2015).

Viet Nam has integrated more to the global economy. Notably, the country together with 11 other member countries reached the TPP on 5 October 2015, which is considered the most important trade agreement, having biggest impacts on the national economy in the coming times. The TPP does not only bring great opportunities for Viet Nam in the economic development, but also require the Government for the promotion of core labour rights, comprising: freedom of association and the effective recognition of the right to collective bargaining; the elimination of all forms of forced or compulsory labour; abolition of child labour; and the elimination of discrimination in respect of employment and occupation; acceptable conditions of work with respect to minimum wages, hours of work, and occupational safety and health based on an equal footing between the nationals and foreign migrant workers (Article 19.1\&3, Chapter 19 of the TPP).

At regional level, the enforcement of AEC will definitely increase the number of foreign migrant workers in Viet Nam in the near future as mentioned above. Enterprises are expected to receive more foreign migrant workers in Viet Nam. For example, according to the Director General of Robenny Corporation its company has received applicants from Cambodia. Other enterprises reveal their attempts to recruit more workers from other ASEAN countries, particularly the Philippines to work in Viet Nam (Khanh, 2015).

\subsection{Shortage of Skilled Workers in the Vietnamese Labour Market}

According to the statistic the country's workforce comprises 54.6 million in 2015 of which the employed workforce comprises 78.8 per cent. The unemployment rate accounts for 2.18 per cent (GSO, 2015). Viet Nam is still in the era of golden population like what some other Asian countries such as Singapore, Japan experienced in the past. Meanwhile the population above the age of 65 is 10 per cent in China and approximately 13per cent in South Korea this population only accounts for 6per cent in Viet Nam (Rina, 2015). The Vietnamese workforce is relatively young. The workers between 15 and 39 years of age account for 51.2 per cent of the total workforce (GSO, 2015).

The literacy rate of the Vietnamese is high, accounting for 94.7per cent (GSO, 2012). However, the country is facing a severe shortage of skilled workers due to the educational system which fails to meet the labour market demands. The rate of unskilled workers who do not obtain vocational training degrees comprise 43.76 million, accounting for 81.4 per cent (GSO, 2014). Over 22 million Vietnamese workers who do not obtain vocational diplomas and certificates are working in the occupations which require for technical skills. Meanwhile, 750 thousand workers obtained bachelor diplomas and higher are engaging in low skilled 
work. The Vietnamese educational system weakness has led to a problem that the trained occupations are unsuitable to the labour market. Graduates from Universities and vocational training institutions generally do not meet the work demands. In Ho Chi Minh City, for example, only 15 percent of graduates of Information and communication technology (ICT) meet the enterprises' requirement. Over 80 per cent of computer programmers must be retrained by their enterprises (Tran, 2014).

According to the survey report conducted between the Institute of Labour and Social Affairs and Manpower Company one third of the surveyed enterprises revealed their inability to find workers who obtain suitable skills (Hoang, 2014). Meanwhile, the unemployment rate among people who obtain University diplomas or higher accounts for 16.9 per cent, which is much higher than the average unemployment rate (MOLISA, 2014). This practice reflects the inappropriateness between the vocational training system and the use of labour of which the vocational and occupational training is not suitable to the labour market (Ibid.,). The representative of the Vocational Training Department admitted: 'we have been focused mainly on vocational training at University level for years. 80 per cent of high school graduates enrolled in Universities. This explains the practice that the University graduates are working in the sectors unsuitable to their qualifications (Ibid.,).

According to the World Bank over 60 per cent of foreign invested enterprises in Viet Nam view the shortage of qualified workers as a challenge to their activity. Employers view the workers' inadequate skills as a more serious concern than labour market regulations and taxes. A majority of employers are facing the difficulty in employing new workers either because of inadequate skills of job applicants, particularly in technical, professional and managerial occupations, or because of a shortage of workers in certain low skilled occupations (World Bank, 2013).

\subsection{Low Labour Productivity in the Vietnamese Labour Market}

Labour productivity of Viet Nam increases by 3.9 per cent in the period of 2006-2015, which was calculated based on the total Gross Domestic Product (GDP) and the total employed persons. However, it remains low compared with other ASEAN countries. In 2015 the labour productivity was estimated at VND 79.3 million per worker (equivalent to around US\$ 3,657). The labour productivity calculated based on purchasing power parity (PPP) of Viet Nam in 2013 was US\$ 5,440. Meanwhile, this amount is also lower than other ASEAN countries. For example, the PPP of Singapore was US\$ 98,072, Malaysia: US\$ 35,751; Thailand: US\$ 14,754; Indonesia: US\$ 9,848 and the Philippines: US\$ 10,0263 (GSO, 2016).

Agro-forestry and fishery still plays the significant role in the whole Vietnamese economy. The annual increase of labour productivity in this sector is 3.3 per cent, however, the labour productivity in the industry and construction sector increases by 1.7 per cent and Services Sector increases by 2.8 per cent. However, the labour productivity value of Agro-forestry and Fishery Sector remains lowest, which only amount to VND 31.1 million/worker (approximately US\$ 1,400), contribute to 39.2 per cent of the total labour productivity of the whole economy in 2015. This amount was VND 133.6 million (approximately US\$ 6,072) in the Industry and Construction Sector and VND 106.6 million (approximately US\$ 4,800) in 
the Services Sector (Ibid.,).

\subsection{Contribution of Foreign Migrant Workers to the Vietnamese Labour Market and Economy}

The Vietnamese labour market currently depends on foreign migrant workers, particularly skilled workers to fill vacant positions which the Vietnamese are disqualified. The number of foreign migrant workers in Viet Nam constantly increases. According to the statistic the number of registered foreign migrant workers increased by 76,309 foreign workers in 2014, of which 55,263 foreigners were granted work permits, accounting for 78.18per cent. 15,436 foreigners were in the process of work permit application dossier consideration, accounting for 21.83 per cent and 5,610 workers were exempted from work permits, accounting for 7.35per cent (Le, 2015).

The foreign migrant workers come from 74 nationalities, who mainly from countries in Asia comprising China, Japan, South Korea, Malaysia, Taiwan, etc., accounting for 58 per cent, Europe accounting approximately 28.5 per cent and 13.5 per cent of foreigners come from other countries. The high-skilled workers obtaining at least university diplomas account for 48.3 per cent; and technical workers account for 34.6 per cent (Ibid.,).

The skilled foreign migrant workers are contributing to the development of the Vietnamese economy, particularly in response to the problems on shortage of skilled labour and low labour productivity in the Vietnamese labour market. Most of the managers, senior and medium technical specialists in foreign organisations and enterprises in Viet Nam are foreigners (Pham, 2011). In Ho Chi Minh City, there are over 20,300 foreign migrant workers working in approximately 5,500 enterprises and organizations, 55 per cent of whom are managers. The majority of foreign migrant workers in the city come from Japan, South Korea, the United States, the United Kingdom, China, Taiwan (Trung Son, 2015).

According to the survey findings conducted by GSO, the presence of foreign migrant workers has created a positive impact on the labour productivity of the Vietnamese workers. Accordingly, every 01 per cent increase in the number of foreign skilled migrant workers leads to the increase of 0.91 per cent of the total labour productivity in the enterprises (GSO, 2016).

\section{The New Labour Migration Policy}

\subsection{Work Permit Regime}

The number of illegal foreign migrants who entered Viet Nam to carry out manual work has increased in recent years, which is officially reported to be 44 per cent. However, this data is estimated higher in practices. The Africans constitute the majority of the illegal foreign labour. Together with the rising number of illegal African workers, the Vietnamese authority bodies are facing a challenge from illegal foreign labour from China (Xuan Thao, 2013).

On the one hand, the Chinese contractors who successfully won the bids in infrastructure projects in Viet Nam prefer to employ the Chinese workers. It is reported that thousands of Chinese workers are working illegally in the Central Highland Provinces, Khanh Hoa, Phu Yen Provinces (Ibid.,). On the other hand, there was a number of local authorities ignored the 
practices that admitted illegal foreign migrant workers in order to attract foreign investment in their respective localities. For example, the authority bodies of Ha Tinh Province allowed a Taiwanese steel plant investor to bring thousands of Chinese nationals into the country without work permits. According to the Management Board of Ha Tinh Economic Zones over 3,000 out of 4,000 Chinese nationals worked illegally in the Formosa Ha Tinh construction sites (Vietnamnet News, 2014). Similar situations happen in other localities. For example, 130 out of 289 Chinese workers are reported to work illegally in Vinh Tan hydroelectric power plant, Binh Thuan province (Nguyen Nam, V. Lam, Th. Tri, 2016)

The state management weakness is another reason for increased illegal migrants. For example, the authority bodies of Khanh Hoa Province only grants work permits to approximately 500 foreign migrant workers in 60 enterprises in the province. The number of illegal foreign migrant workers is much higher in practices (An ninh, 2015). Competent bodies fail to coordinate with each other's in the management of foreign labour in Viet Nam of which no authority bodies take the key responsibility for the weakness in management of foreign labour.

The increased number of illegal foreign migrants to carry out manual work has created a negative response from the Vietnamese Government in order to restrict the use of foreign labour in Viet Nam. For example, on August 09, 2012 MOLISA promulgated a document No 2761/LĐTBXH-VL which required all Presidents of the provincial People's Committees to strengthen the management of foreign migrant workers in Viet Nam. Similarly, the Director of the State Bank of Viet Nam promulgated document No 7497/NHNN-TTGSNH dated 10 October 2013 on strengthening the management of foreign migrant workers who carry out work in credit organizations, branches of foreign banks and other representative offices of foreign organizations operating banking activities in Viet Nam.

The work permit regime becomes stricter. The Vietnamese Government continuously affirms to admit only skilled foreign workers, comprising managers, executive directors, specialists and technical workers to carry out the work of which the Vietnamese workers' qualifications fail to meet the demands of productions and business activities (Note 4). Earlier, the terminology on 'foreign worker' was defined broader. It referred to the foreigner who does not hold the Vietnamese nationality (Note 5). The 2012 Labour Code narrows this terminology. Accordingly, a 'foreign migrant worker' is defined by law as a foreign citizen who enters Viet Nam to work (Note 6). This definition limits those who are citizens of other countries. Other types of foreigners, for example, the stateless persons or refugees are excluded. Meanwhile, in other ASEAN countries the term "foreign worker" is defined broader. For example 'foreign worker' is defined as any foreigner who looks for a job or is offered a job in Singapore (Note 7). In Thailand, the term "Alien" is used to refer to a natural person who does not obtain Thai nationality (Note 8).

The new Law on immigration and residence of foreigners requires foreigners to obtain the work permits as a condition to be granted the visa to enter Viet Nam to carry out work (Note 9). It means that the work permit should be applied by the enterprises and organizations recruiting the foreign migrant workers, and granted by the authority bodies to the foreign 
migrant workers before their entry to Viet Nam. The duration of work permit reduces by not more than 2 years compared with the 03 year period as prescribed in the former law (Note $10)$.

However, facing the foreign investment pressure, the influence of joining TPP and AEC recently, the Vietnamese Government has introduced a new law regulating the employment of foreign labour. In general, this new law reflects a more open policy towards foreign migrant workers compared with the former Decree No 102/2013.

According to the new law, the use of foreign migrant workers in undertakings must be approved by the Vietnamese authority bodies. Annually, employers are responsible for making the proposal on their demands for employment of foreign migrant workers concerning specific types of work of which the Vietnamese nationals do not meet the qualifications. This proposal must be submitted to the Presidents of the provincial level People's Committees for approval. Any change in the foreign labour employment must also be reported to the Presidents of the provincial level People's Committees (Note 11).

However, the new Decree No 11/2016/NĐ-CP does not require employers to report on the use of foreign migrant workers who work in Viet Nam less than 03 months to make offer on the sale of services; or those who come to Viet Nam to deal with technical issues which are beyond the capacity of the Vietnamese and foreign specialists who are working in Viet Nam; foreigners who are specialists, managers, executive directors or technical workers who work less than 30 days or not longer than 90 days in 01 year; foreign apprentices in organizations and enterprises in Viet Nam (Note 12).

A manager must be the head or deputy head of an enterprise or organization; an executive director must be the head of the enterprise or organizations' branch. A foreign specialist must obtain a written attest from his/her enterprise or organization in the foreign country affirming that he/she is the specialist. In addition, he/she must obtain at least a bachelor diploma or equivalent in the relevant field. A technical worker must obtain the diploma from a technical school with the training duration of at least 01 year. The new law has reduced the working experience requirements for foreign specialists and technical workers from 05 years as required in the former law to 03 years (Note 13).

In order to be granted the work permit a foreigner must obtain a full civil capacity act; have health conditions meeting the work requirement; to be a manager, or executive director, or specialist or technical worker; he/she is not a criminal or prosecuted for criminal liability; is accepted in written documents by the competent authority body (President of the provincial level People's Committee) on the use of foreign labour (Note 14).

The foreign migrant worker is required to submit a criminal record provided by the competent authority bodies of his/her home country, stating that he/she is not a criminal or prosecuted for criminal liability. This criminal record must be granted within 06 months since the date of dossier application. However, concerning this issue there is a positive change in the new law. Accordingly, a foreign migrant worker who is residing in Viet Nam only needs to obtain a criminal record provided by the Vietnamese competent authority bodies. 
Meanwhile the former Decree No 102/2013/NĐ-CP required foreign migrant workers residing in Viet Nam to refer the criminal records issued by the competent bodies in their home countries (Note 15).

Within 07 working days, since the date of receiving the appropriate dossier the provincial level Department of Labour, Invalids and Social Affairs grants the work permit to the foreign migrant worker (Note 16). This is another positive change of the new law. Under the former law this duration, it was 10 working days. (Article 12 Clause 2 of the Decree No 102/2013/NĐ-CP). Actually, however, this duration usually takes at least 2 months (Minh Tam, 2014). In order to guarantee the implementation of this new legal provision, it will require a big commitment of the authority bodies in the coming time.

The Government has developed new laws which apply sanction on both employers who employ illegal foreign labour and the foreign migrant workers who are working illegally in Viet Nam. Accordingly, employers who employ illegal foreign migrant workers are liable to a fine between VND 30,000,000 and 45,000,000 (approximately US\$ 1,420-2,058) for employing between 01 and 10 foreign migrant workers or between 45,000,000 and 60,000,000 (approximately US\$ 2,058-2,745) for employing between 11 and 20 foreign migrant workers or between 60,000,000 and 75,000,000 (approximately US\$ 2,745-3,431) for employing over 21 foreign workers. In addition, the employers may be suspended the enterprise operation between 01 and 03 months (Note 17).

Foreign migrant workers working illegally in Viet Nam may be subject to deportation (Note 18). However, as a matter of fact,the issue on illegal foreign migrant workers has not been resolved due to the poor management of foreign labour mentioned above.

\subsection{Residency Security}

During the working period in Viet Nam, foreign migrant workers are granted temporary resident cards, which are renewable depending on the work permit duration. However, regardless how long the work permit holders have lived in Viet Nam the permanent residency policy remains strict. It is only granted to the foreign migrant workers in exceptional circumstances, for example, where the foreigner has made a contribution to the development and protection of Viet Nam and is granted a state level medal or other state honor prize; or if the foreigner is a scientist/specialist who is temporarily residing in Viet Nam. The Minister, Heads of Ministerial Equivalent Agencies, Governmental bodies in the specialized field shall decide and recommend the foreigner who is scientist/specialist to be granted the permanent residency.

Other types of foreigners eligible to permanent residency include the foreigners whose mothers, fathers, wives, husbands or children are Vietnamese citizens residing in Viet Nam and act as the guarantors for the foreigners or stateless persons who have constantly resided in Viet Nam since the year of 2000 or earlier. In all circumstances the foreigners must prove that they have legal place of residence and permanent income to guarantee their lives in Viet Nam (Note 19).

Similarly, it is extremely difficult for the foreigners to be granted the Vietnamese nationality. 
Accordingly, the foreigners must obtain full civil capacity and have permanently resided in Viet Nam for at least 05 years; have sufficiently financial capacity to guarantee their livelihood in Viet Nam. In addition, the foreigners must speak Vietnamese; obey Vietnamese Constitution and laws; respect the Vietnamese culture, customs and practices. Exemption from the requirements for 05 year permanent residency; financial sufficiency; and Vietnamese proficiency are granted to foreigners who are wives, husbands, biological fathers/mothers or children of the Vietnamese citizens; or foreigners who made a great contribution to the Vietnam's national construction and defense; or other foreigners who are deemed helpful to the Viet Nam (Note 20).

The rights to housing foreigners in Viet Nam have been granted for the first time. And the right to own apartments and houses in the building projects in designated areas was regulated by the Government since 1 July 2015. However, this ownership is recognized in a period of 50 years (Note 21 ).

\subsection{Equal Treatment and Employment Security at the Workplaces}

Viet Nam is a signatory to the Convention of the International Labor Organization (ILO) No 111 on discrimination (employment and occupation), 1958 and the Convention No 100 on equal remuneration. In order to fulfill its obligations in the two above mentioned Conventions the principle on non-discrimination in employment and occupation is acknowledged in the 2012 Labour Code. Discriminating on the basis of sex, race, colour, social class, marital status, belief, religion, HIV status, disabilities at the workplace are among the prohibited acts (Note 22). As a result, the foreign migrant workers are enjoying equal treatment compared with the Vietnamese workers before the laws.

The foreign migrant workers are entitled to work for different employers as well as to change employers. However, they are more likely suffered from disadvantages due to the language, cultural difference, their shortage of knowledge on the Vietnamese legal and political system. Moreover, the civil society organizations in Viet Nam are under-developed. There are no civil society organizations focusing on protecting and supporting the foreign migrant workers. Employers are not obliged by law to make a deposit in event of repatriation, compensation for the foreign migrant workers in the event of occupational accidents and diseases, employment injury benefits; job loss. Consequently, the foreign migrant workers are more vulnerable than the Vietnamese workers. They are easily become victims of fraud acts when entering the labour market in Viet Nam.

International evidence shows that international migrants who are away from their home community tend to face vulnerabilities which are created from moving between different social security and assistance system, social service system and labour market. Their access to both informal social network and safety nets and formal social service system in the host countries are often limited (Rachel \& Linnet, 2010). Foreign migrant workers in Viet Nam are often in vulnerable positions from employers 'malpractices. For example, on April 9,2012 Raffles Viet Nam, Ho Chi Minh city branch (herein after referred to as Raffles Ho Chi Minh City) unilaterally terminated the employment contracts with its 5 foreign teachers namely $\mathrm{S}$. Franziska, N. M. Baudisch (German citizens), A. C. Ayuso (British citizen), J. L. Flaten (US 
citizen) and P. D. Neyroud (Swiss citizen) (herein after referred to as the plaintiffs). The plaintiffs brought the case to the Court of Phu Nhuan district, Ho Chi Minh City. On July 2012 the Court of Phu Nhuan district officially denied the claims of the plaintiffs due to the fact that their employment contracts were concluded inconsistent with the Vietnamese law (invalided employment contracts). As the result, the plaintiffs' claim for compensation was denied by the Court (Le Nga, 2012).

Due to their lack of knowledge about the Vietnamese labour laws the rights and interests of these foregn migrant workers were not protected. If they received proper guidance and consultation on their lawful rights and interests before entering into employment contracts their employment contracts would not have been announced invalid by the Court; and they would have received adequate compensation and other benefits as prescribed by law when their concluded employment contracts were illegally unilaterally terminated by Raffles Ho Chi Minh City.

\subsection{The Right to Establish or Join Trade Unions}

Viet Nam has ratified 20 conventions of the International Labor Organisation, ILO but not the Freedom of Association and Protection of the Right to Organize Convention (No. 87) and the Right to Organize Convention (No. 98). Nevertheless, Article 69 of the Constitution guarantees "the right of assembly, association and demonstration in accordance with the law". As the socialist country the Viet Nam General Confederation of Labour (VGCL) is the only statutorily recognized Trade Union (Note 23). The 2012 Trade Union Law excludes the right to trade unions of foreign workers. Accordingly, no foreign migrant workers are entitled to either establish or join Trade Unions during their working periods in Viet Nam. According to the ILO Committee on Freedom of Association workers without distinction whatsoever concerned, to join organizations of their own choosing without previous authorization. The law should permit foreign migrant workers to access to Trade Union posts, at least after a reasonable period of residence in the host country (ILO, 2006). Freedom of association including the workers' right to join and form Trade Unions of their own choosing is recognized under Chapter 19 of the TPP as mentioned above. Independent Trade Unions other than VGCL will be able to establish and operate in Viet Nam. However, until now there is no detail legal document regulate this issue.

Protecting legal and legitimate rights and interest of workers' collective and workers is one of the rights and responsibilities of Trade Unions which apply on both the Trade Union members and the non-unionized workers, including the foreign migrant workers (Note 24). However, there is hardly a reported case of which the VGCL are exercising their rights and responsibilities on protecting the lawful rights and interests of the foreign migrant workers in Viet Nam, particularly when their rights and interests are violated by the employers.

\subsection{Social Security Protection}

The Universal Declaration of Human Rights recognizes the right of everyone and his family, including the right to security in the event of unemployment, sickness, disability, widowhood, old age or other lack of livelihood in circumstances beyond his control (Note 25). Social 
security protection for international migrants may consist four factors: the access to formal system of social security and social services in the host countries and countries of origin; the portability of social security rights between the host countries and countries of origin; labour market conditions for international migrants in the host countries and the recruitment process for migrants in the countries of origin; access to informal networks to support migrants and their family members (Rachel \& Linnet, 2010). However, the social security protection for foreign workers in Viet Nam remains limited.

The foreign migrant workers were not granted the right to join the medical insurance scheme, which covers the health check-up and medical treatment expenses until July 1, 2009 (Note 26). Under the amended Social Insurance Law foreign citizens who obtain work permit to carry out work in Viet Nam shall be entitled to join compulsory social insurance scheme which covers such benefits as sickness; maternity; employment injury; retirement and survivorship allowance from January 1, 2018 (Note 27). This is a positive change in the protection of foreign workers' social security rights in Viet Nam in the coming years. However, it is not clear how this legal provision will be implemented since the Vietnamese Government has not issued any implementation Decrees and Circulars with this regards.

Moreover, foreign migrant workers are not entitled to join and benefit from unemployment scheme in the event of unemployment as prescribed in the new Employment Law of 2013 (Note 28). Consequently, this legal provision still creates a financial burden for foreign migrant workers in Viet Nam who lose their jobs. Another remained problem is workers in Viet Nam are facing a risk that the Social Security Fund (VSS) will be unable to pay for their social security benefits due to the weakness in management of the VSS. According to the statistics of MOLISA between 50per cent and 75per cent of the operating enterprises have not contributed to the social security schemes. From the worker's side only 11 million workers out of 16 million eligible workers, accounting for 68.8per cent participate in the compulsory social insurance schemes. This created a loss for the VSS of approximately VND 56,000 billion (around US\$ 2.55 billion). Other enterprises are in debt of VND 11,000 (around US\$ 501 million) to VSS (Pham, 2014).

The above mentioned problem mainly arises from the labour inspection weakness. In addition, the number of labour inspectors remains limited compared with the big number of operating enterprises. The total number of inspectors at the MOLISA level includes 50 officials and another 3,000 officials in all cities and provinces. Ho Chi Minh City has the highest number of inspectors with 33 inspectors, followed by Hanoi with 10 inspectors. Many Provinces and localities only count 2 inspectors, meanwhile, there are over 400,000 enterprises in the whole country (Nguyen Hong Ha, 2013). The ILO made a prediction that 'the VSS could start having deficits by 2021 and experience depletion by 2034 if no reforms are made' (ILO, 2013). Therefore, an appropriate social security policy is needed to strengthen the regulation and operation of the VSS in order to guarantee and promote benefits of the social protection for foreign migrant workers in Viet Nam.

Experiences in other countries, for example, India may offer an interesting input for Viet Nam in promulgating implementation legal framework to regulate in details the contribution 
of the foreign migrant workers to the Vietnamese Social Security Fund. Under the Act No 19 of 1952 of India foreign workers are required to join the compulsory India's security scheme. The foreign workers and their employers must equally contribute 12 per cent of the workers' actual wages, comprising basic wages and allowances to the Indian's social security schemes. Upon job termination the foreign workers in India are entitled to withdraw the full amount of contributed credits from the Employee's Provident Fund. Where the foreign workers are from countries having signed the social security agreements with India the withdrawal from the Employee's Provident Fund shall be payable in the payee's bank account directly or through the employer. In all the other cases, the amount withdrawn will be credited to international workers' Indian bank account.

In addition, Viet Nam should try to promote different forms of social security cooperation, including entering into bilateral and multilateral social security agreements as one of the effective measures to protect the social security entitlements of foreign migrant workers in Viet Nam and guarantee the 'exportability' of benefits which refer to the benefits acquired in their home countries or other countries are payable in the Viet Nam and vice versa.

\section{Discussion and Conclusion}

Viet Nam has become a new destination of foreign invested enterprises. However, one of the biggest challenges that the enterprises, particularly foreign invested enterprises are facing is the shortage of skilled labour and the low labour productivity of the Vietnamese workers. It is a considerable weak point of the Vietnamese economy. The Government, with the enactment of the Foreign Investment Law in 1987, aimed at the transfer of technology, and occupational skills and knowledge from foreign invested enterprises to the Vietnamese. However, this expectation has not been realized until now. Although the presence of the foreign invested enterprises has contributed to generating employment for the Vietnamese its economic efficiency remains low. Foreign invested enterprises in Viet Nam mainly are labour intensive enterprises which engage in low-value production and assembly work, particularly automobile assembly, electronics, garment and textile and leather shoes. In addition, the production materials in Viet Nam are heavily dependent on the import. It accounts for 87 percent in the telephone sector; 92 per cent in the electronics, computers and electronics chips; 62 per cent in garment sector and 67 percent in leather shoes sector (GSO, 2014a).

The country has a lot of strong points to attract skilled foreign migrant workers. The Vietnamese are one of the most capable and energetic people in Southeast Asia (Lee, 2013). In addition, it has a young population and an interesting cultural diversity and other natural benefits such as 'sun, sea, and sand'. The living cost is low, etc. Unfortunately, the immigration strategy remains unattractive as mentioned above. Despite the open policy to attract foreign investment, Viet Nam maintains a close immigration policy for many years. The first major reason is the reluctance of the law and policy-makers to admit foreigners to work in Viet Nam as the influence of political and security scenarios from the post-Viet Nam/American War. The second major reason is the unemployment pressure among the young Vietnamese. For the foregoing reasons the problem of illegal foreign migrants has not been settled particularly concerning unskilled workers. As the result, it has negatively 
affected the employment of local workers.

The foreign migrant workers, particularly the skilled workers are playing a significant role in the Vietnamese economy development in the current context of severe shortage of local high skilled workers as mentioned above. However, the role of foreign labour in the economic development has not been adequately encouraged. It is extremely difficult for foreigners to be granted permanent residency in Viet Nam or the Vietnamese nationality. Their core rights at the workplace are still not fully guaranteed at the workplace as analyzed before.

The enforcement of the AEC agreement definitely creates challenges for both Vietnamese policy makers and the workers. One of these challenges is a bigger competition between the Vietnamese workers and foreign migrant workers; employers are created more chances to 'shop around' among the workers. However, these challenges are also opportunities. Labour competition between Vietnamese workers and foreign migrants will lead to the development of the local labour market, and the improvement of Vietnamese workers' skills. Moreover, the local vocational training should be more practical, which are tailored more suitable to the needs of the labour market. The Vietnamese Government should not forget that gains from migration and protection of migrant rights are indeed inseparable. Migrant workers can make their best contribution to economic and social development in host and source countries when they enjoy decent working conditions, and when their fundamental human and labour rights are respected (Juan, 2006).

The golden population period will not last long in Viet Nam as what happened in other countries. Investment encouragement policy aiming at foreign invested enterprises will also not last long, because the government should also equally treat domestic enterprises and foreign invested enterprises. Thus, foreign investment encouraging policies in the forms of tax reduction; and reduction of land use fees, land lease fees, etc. will gradually reduce. Skilled labour force will be the decisive factor to push up the economy. Given the fact that, the skilled labour immigration is crucial and decisive for growth and wealth of nations in the 21 st century (Thomas, 2000).

In order to keep its competitiveness in the region, the Vietnamese Government should aware that the highly skilled people have the opportunity to communicate and sell their knowledge around the globe. If so, they can choose their place of residence by maximizing the expected return on their human capital investments (Ibid.). Given the reasons as mentioned above, the government should adopt a more open migration policy to push up the high-technological economy in Viet Nam. These measures may settle the problem on local skilled labour insufficiency and low labour productivity in the short term. Consequently, there will be more opportunities for skilled foreign migrant workers to transfer technological knowledge and skills to the Vietnamese in the long term.

If the problem on shortage of skilled workers remains, the country will gradually lose its attraction to foreign enterprises compared with other ASEAN countries. Consequently, Viet Nam would still be the 'world factory', where foreign invested enterprises produce cheap products employing labour-intensive workers at low cost. 


\section{References}

Asian Development Bank, ADB \& International Labour Organisation, ILO (2014). ASEAN Community 2015: Managing integration for better jobs and shared prosperity Retrieved July 18, 2016 from http://www.adb.org/sites/default/files/publication/42818/asean-community2015-managing-integration.pdf

An ninh, T. V. (2015). Illegal foreign labourers in Khanh Hoa province" (in Vietnamese). Retrieved December 10, 2015, from http:/www.antv.gov.vn/tin-tuc/xa-hoi/ van-de-lao-dong-nguoi-nuoc-ngoai-trai-phep-tai-khanh-hoa-162588.html

General Statistics Office of Viet Nam [GSO].(2016). Labour productivity in Viet Nam: practices and solutions. Retrieved July 17, 2016, from https://www.gso.gov.vn/Modules/Doc_Download.aspx?DocID=19551

GSO. (2014). Survey report on employment and labour (in Vietnamese). Retrieved May 17, 2016, from http://www.gso.gov.vn

GSO. (2015). Survey report on employment and labour in Quarter 4 of 2015 (in Vietnamese). Retrieved May 17, 2016, from http://www.gso.gov.vn

GSO. (2012).General survey on the population and family planning on 1 April 2012 (in Vietnamese). Retrieved May 17, 2016, from http://www.gso.gov.vn

Hoang, H. (2014). It is difficult to improve labour productivity. (in Vietnamese). Retreived July 15, 2016 from http://www.doanhnhansaigon.vn/van-de/kho-cai-thiennang-suat-lao-dong/1085008/

HSBC (2014). How countries compare. Retrieved March 29, 2015 from http://expatexplorer.hsbc.com/survey/\#/country/Viet Nam

International Labor Organization [ILO].(2006). Freedom of Association: Digest of decisions and principles of the Freedom of Association Committee of the Governing Body of the ILO. Geneva: ILO.p. 45

ILO. (2010). International Labour Migration: A rights based approach. Geneva: ILO.p. 18

ILO. (2011). Social Security for Migrant Workers A rights-based approach. Geneva: ILO.p.

ILO. (2013). Actuarial Valuation of the public pension scheme of the Viet Nam Social Security Fund. Retrieved December 11, 2015, from http://www.ilo.org/hanoi/Informationresources/Publicinformation/Pressreleases/WCMS_220 046/lang--en/index.htm

Juan, S. (2006). Roundtable 3 on Globalization and labour migration ECOSOC High-level Segment, Geneva

Hyunjoo, J. (2015). Samsung Elec says halts TV production in Thailand". Retrieved July 17, 2016 , from http://www.reuters.com/article/us-samsung-elec-thailand-idUSKBN0O60AF20150521 
Khanh, L. (2015).Viet Nam is expecting a big number of foreign labour from ASEAN countries (in Vietnamese). Retrieved May 17, 2016 from http://cafef.vn/vi-mo-dau-tu/viet-nam-chuan-bi-don-luc-luong-lao-dong-lon-tu-cac-nuoc-asea n-20151230105733522.chn

Le, P. (2015). Managing foreign labourers in Viet Nam: harmonization of demands and interests" (in Vietnamese). Retrieved December 9, 2015, from http://laodong.com.vn/viec-lam/quan-ly-lao-dong-nuoc-ngoai-tai-viet-nam-hai-hoa-giua-yeucau-va-loi-ich-294233.bld

Lee, K. Y. (2014). One man's view of the world (p. 194). Singapore: Straits Times Press, Le, N. (2012). 5 foreign teachers sue Raffles Viet Nam. Retrieved July 17, 2016 from http://thanhnien.vn/thoi-su/5-giao-vien-nuoc-ngoai-khoi-kien-raffles-viet-nam-487246.html

Ministry of Planning and Investment [MPI].(2015). Foreign investment in Viet Nam in 2014" (in Vietnamese). Retrieved December 8, 2015 from http://fia.mpi.gov.vn/tinbai/2569/ Tinh-hinh-DTNN-tai-Viet-Nam-nam-2014

MPI. (2016). Foreign direct investment in Viet Nam reached US\$24.1 billion in 2015" (in Vietnamese). Retrieved May 25, 2016 from http://fia.mpi.gov.vn/tinbai/4310/VietNam-thu-hut-24-1-ty-USD-von-dau-tu-truc-tiep-nuoc-ngoai-nam-2015

Minh, T. (2014). Enterprises criticize the state management of foreign labour (in Vietnamese). Retrieved July 19, 2016 from http://www.thesaigontimes.vn/123810/Doanhnghiep-keu-chuyen-quan-ly-lao-dong-nuoc-ngoai.html

Nguyen, N., Lam, V., \& Tri, Th. (2016). Illegal Chinese workers (in Vietnamese). Retrieved May 17, 2016 from http://cafef.vn/lao-dong-trung-quoc-lam-chui-20160419092638929.chn

Nguyen, H. H. (2013). Strengthening the involvement of the employers in settling challenges on industrial relations in the South (in Vietnamese).Viet Nam Chamber of Commerce and Industry, Ho Chi Minh Branch (Unpublished report).

Ngan, A. (2014). Vietnam inherits factories from manufacturers fleeing China. Retrieved December 9, 2015, from http://www.thanhniennews.com/business/vietnaminherits-factories-from-manufacturers-fleeing-china-36771.html

Pham, M. H. (2011). Foreign labour in Viet Nam seen from another point of view (in Vietnamese). Retrieved July 19, 2016 from http://vov.vn/vov-binh-luan/lao-dongnuoc-ngoai-tai-viet-nam-goc-nhin-khac-183387.vov

Pham, H. (2014). Social Insurance Fund break-up, an alarming problem? (in Vietnamese). Retrieved December 11, 2015, from http://m.vietnamnet.vn/vn/kinh-doanh/ 174458/vo-quy-bao-hiem-nhung-bao-dong-dang-so.html

Rina, C. (2015). Meet Asia's New Manufacturing Powerhouse: Vietnam. Retreived from http://www.bloomberg.com/news/articles/2015-04-01/meet-asia-s-new-manufacturing-power house-vietnam 
Rachel, S.-W., \& Linnet, T. (2010). Welfare Provisions for Migrants: Current Trends: World Migration Report 2010 Background Paper.

Future Challenges, International Organization for Migration, Retrieved July 19, 2016, from http://publications.iom.int/system/files/pdf/wmr2010_welfare_provision_for_migrants.pdf

Thomas, S. (2000). International Mobility of the Highly Skilled: Brain Gain, Brain Drain or Brain Exchange. Hamburg: Hamburg Institute of International Economics.

Tuoi Tre News. (2015a). Intel to move part of production from Malaysia to Vietnam. Retrieved December 9, $2015 \mathrm{http}: / /$ tuoitrenews.vn/business/28501/intel-to-movepart-of-production-from-malaysia-to-vietnam

Tuoi Tre News (2015b).Vietnam surpasses Malaysia, Thailand to become ASEAN's biggest exporter to US. Retrieved December 9, 2015, from http://tuoitrenews.vn/business/ 26328/vietnam-surpasses-malaysia-thailand-to-become-aseans-biggest-exporter-to-us

Tran, A. T. (2014). Shortage and weakness (in Vietnamese). Retreived December 10, 2015, from http://www.dubaonhanluchcmc.gov.vn/tin-tuc/4665.diep-khuc-thieu-va-yeu.html

Trung, S. (2015). More than half of foreign labourers in Ho Chi Minh City are managers (in Vietnamese). Retrieved May 17, 2016, from http://vnexpress.net/tin-tuc/thoi-su/honnua-lao-dong-nuoc-ngoai-tai-tp-hcm-la-sep-3315766.html

United Nations, UN. (2015). International Migrant Stock 2015. Retrieved July 17, 2016 from http://www.un.org/en/development/desa/population/migration/data/estimates2/estimates 15.sht $\mathrm{ml}$

United Nations Conference on Trade and Development. (2014).World Investment Report 2014. Retrieved March 28, 2016, from http://unctad.org/en/Pages/DIAE/Worldpercent 20Investmentper cent 20Report/Country-Fact-Sheets.aspx

Viet Nam Center for Industrial Relations Development, CIRD. (2012). Master plan for industrial relations development in Ho Chi Minh City in the period 2013-2020 (in Vietnamese). CIRD unpublished report.

Viet Nam Customs. (2015). Import and export of Viet Nam in August and 8 months of 2015 (in Vietnamese). Retrieved from http://www.customs.gov.vn/Lists/ThongKeHaiQuan/ ViewDetails.aspx?ID $=847 \&$ Category $=\mathrm{Ph} \% \mathrm{C} 3 \% \mathrm{~A} 2 \mathrm{n} \% 20 \mathrm{t} \% \mathrm{C} 3 \% \mathrm{ADch} \% 20 \% \mathrm{C} 4 \% 91 \% \mathrm{E} 1 \%$ BB\%8Bnh\%20k\%E1\%BB\%B3\&Group=ph\%C3\%A2n\%20t\%C3\%ADch (December 9, 2015)

Vietnamnet News. (2014). Thousands of Chinese workers in Vung Ang have not obtained work permits (in Vietnamese). Retreived December 10, 2015, from http://m.vietnamnet.vn/vn/xa-hoi/200983/hang-nghin-lao-dong-tq-o-vung-ang-chua-co-phep. html

World Bank. (2013). Viet Nam Development Report 2014: Skilling up Viet Nam: Preparing the workforce for a modern market economy. Retrieved March 28, 2016, from 
http://documents.worldbank.org/curated/en/2013/11/18556434/VietNam-development-report2014-preparing-work-force-modern-market-economy-vol-2-2-main-report

Xuan, T. (2013). Weakness in managing foreign labourers in Viet Nam (in Vietnamese). Retrieved uly 7, 2016 from http://www.baohaiquan.vn/Pages/Bat-cap-trong-quan-ly-laodong-nuoc-ngoai-tai-Viet-Nam.aspx

\section{Notes}

Note 1. Article 7, Article 9 and Article 10, Regulation No 492/2011 of the European Parliament and of the Council of 5 April 2011.

Note 2. Paragraphs 1, 5, $8 \& 9$ of ASEAN Declaration on the Protection and Promotion of the Rights of Migrant Workers of 13 January 2007.

Note 3. Committee on the Elimination of Racial Discrimination, concluding observations on the initial and second periodic reports of Japan (para. 173).

Note 4.Article 170 Clause 1 of the 2012 Labour Code

Note 4. Article 1 and Article 2 Clause 1 of the former Decree No 34/2008/NĐ-CP dated 25 March 2008

Note 6. Article 169 Clause 1 of the 2012 Labour Code and Article 2 Clause 1 of the Decree No 11/2016/NĐ-CP dated 3 February 2016 which took effect since 1 April 2016 guiding the implementation of a number of Articles of the Labour Code on foreign labourers in Viet Nam in replacement of the Decree No 102/2013

Note 7. Article 2 of the amended Employment of Foreign Manpower Act of Singapore dated 9 November 2012

Note 8. Article 5 of Employment of Foreign Manpower Act of Thailand No B.E. 2551 dated 22 February 2008

Note 9. Article 10 Clause 4c) of the Law on immigration and residence of foreigners in Vietnam dated 16 June 2014. It took effect since 1 January 2015.

Note 10 . Article 11 of the Decree No 11/2016/NĐ-CP.

Note 11. Article 4 Clause 1a of the Decree No 11/2016/NĐ-CP.

Note 12. Article 4 Clause $1 \mathrm{~b}$ of the Decree No 11/2016/NĐ-CP.

Note 13. Article 3 Clauses 3-5 of the Decree No 11/2016/NĐ-CP.

Note 14. Article 9 of the Decree No 11/2016/NĐ-CP.

Note 15. Article 10 Clause 3 of the Decree No 11/2016/NĐ-CP.

Note 16. Article 12 Clause 2 of the Decree No 11/2016/NĐ-CP. 
Note 17. Article 22 Decree No 95/2013/NĐ-CP of August 22, 2013 of the Government on sanctioning administrative violations in the field of labour, social insurance and sending Vietnamese overseas under contracts and took effect since October 10, 2013.

Note 18. Article 18 Clause 1 of the Decree No 11/2016/NĐ-CP.

Note 19. Article 39 and Article 40 of the Law on immigration, transit and residence of foreigners in Viet Nam of June 16, 2014. It took effect since January 1, 2015

Note 20. Article 19 of the Law on Nationality of November 13, 2008. It took effect since July 1,2009

Note 21. Article 59 Clause 2b and Article 161 Clause 2c of the amended Housing Law was approved on November 25, 2014. It took effect since July 1, 2015

Note 22. Article 8 Clause 1 of the 2012 Labour Code.

Note 23. Article 5 Section 1 of the 2012 Trade Union Law and Article 1 of the amended VGCL Statute approved at the VGCL National Congress term XI on 31 July 2013.

Note 24. Article 188 Section 1 of the 2012 Labour Code \& Article 10 of the 2012 Trade Union Law.

Note 25. Article 25 Clause 1 of the Universal Declaration of Human Rights.

Note 26. Article 12 Clause 1 and Article 21 of the Medical Insurance Law dated 14 November 2008.

Note 27. Article 2 Clause 2 and Article 4 of the Vietnamese Social Insurance Law dated 20 November 2014.

Note 28. Article 3 of Employment Law dated 16 November 2013. It took effect since January $1,2015$.

\section{Copyright Disclaimer}

Copyright reserved by the authors.

This article is an open-access article distributed under the terms and conditions of the Creative Commons Attribution license (http://creativecommons.org/licenses/by/3.0/). 